\title{
PENGARUH FASILITAS WISATA DAN PROMOSI TERHADAP MINAT BERKUNJUNG DI DUNIA AIR TAWAR DAN DUNIA SERANGGA TMII
}

\author{
Cicilia Iswidyamarsha ${ }^{1}$, Yudhiet Fajar Dewantara ${ }^{2}$ \\ Program Studi Hospitality dan Pariwisata, Fakultas Ilmu Sosial Dan Humaniora, \\ Universitas Bunda Mulia Jakarta, Indonesia \\ Email : cclmarsha@gmail.com1
}

\begin{abstract}
Abstrak
Penelitian ini merupakan penelitian kuantitatif bersifat deskriptif dengan 100 responden wisatawan. Analisis data menggunakan uji validitas, reliabilitas, uji asumsi klasik, regresi berganda, uji t, uji f, uji korelasi dan determinasi.Hasil uji validitas Fasilitas Wisata, Promosi dan Minat Berkunjung memiliki $\mathrm{r}$ hitung lebih besar dari 0,463 sebagai $\mathrm{r}$ tabel atau semuanya sudah valid. Hasil uji reliabilitas Fasilitas Wisata memiliki Alpha Cronbach 0,653, Promosi memiliki 0,744 dan Minat Berkunjung memiliki 0,757 artinya semua variabel memiliki reliabilitas baik. Hasil uji asumsi klasik memenuhi umsi persyaratan uji regresi berganda. Dari hasil uji $\mathrm{t}$ Fasilitas Wisata secara parsial memiliki pengaruh signifikan terhadap Minat Berkunjung. Selanjutnya Promosi secara parsial memiliki pengaruh signifikan terhadap Minat Berkunjung. Hasil uji F, Fasilitas Wisata dan Promosi secara simultan mempengaruhi Minat Berkunjung. Kesimpulan dalam penelitian yang peneliti lakukan menunjukkan nilai positif dan ketepatan prediksi bahwa ada pengaruh antara Fasilitas Wisata dan Promosi terhadap Minat Berkunjung pada Dunia Air Tawar dan Dunia Serangga TMII. Saran yang diberikan, perlunya meninjau kembali dalam meningkatkan Fasilitas Wisata dan memodifikasi serta aktif dalam Promosi untuk menarik Minat Berkunjung.
\end{abstract}

Kata kunci : Fasilitas Wisata, Promosi dan Minat Berkunjung

\begin{abstract}
This research is a quantitative study that is descriptive with 100 respondent traveler. Data analysis using validity test, reliability, classical assumption test, multiple regression, $T$ test, $f$ test, correlation test and determination. The validity test result of tourism facilities, promotions and visiting interests has $r$ count greater than 0.463 as $R$ table or everything is valid. The results of the reliability Test tour facility has the Alpha Cronbach 0.653, promotion has 0.744 and visiting interest has 0.757 meaning all variables have good reliability. The classic assumption test result fulfills the assumption of multiple regression test requirements. From the results of $T$ Test tour facilities have been partially significant influence on the visiting interest. Subsequent promotions partially have been partially significant effect on visiting interests. F test result, tourism facilities and promotions simultaneously affects visiting interest.Conclusions in the research that researchers do show positive values and accuracy predictions that there is an influence between tourism facilities and promotion of interest in visiting the world of freshwater and insect world TMII. Advice given, the need to review in improving the tourism facilities and modify and active in the promotion to attract visiting interest.
\end{abstract}

Key Words : Tourist Facilities, Promotion and Visiting Interests. 


\section{INTRODUCTION}

Pariwisata secara umum adalah perjalanan atau suatu aktivitas yang dicoba oleh seorang dalam waktu durasi khusus, bisa dalam jangka panjang maupun jangka pendek dari suatu tempat ke tempat lain tetapi tidak untuk menetap. Saat hendak membuat perencanaan perjalanan wisata, tentunya orang yang mempunyai tujuan untuk berwisata akan melakukan berbagai cara sehingga keinginannya dapat terpenuhi, contohnya seperti melakukan olahraga, melakukan perjalanan pendidikan, menjalankan ibadah atau melakukan hobi. Pariwisata juga memiliki manfaat bagi penduduk yang tinggal di sekitaran wilayah suatu objek wisata. Dengan terdapatnya subjek wisata, ditaksir bisa meluaskan daya kegiatan yang dapat menolong tingkatkan ekonomi dan keselamatan masyarakat setempat, serta dapat meningkatkan perolehan devisa negara. Hal ini dikarenakan bahwa pariwisata melibatkan banyak masyarakat dan juga pemerintah serta instansi swasta, yang saling bekerjasama untuk mendapatkan keuntungan bagi masing-masing pihak.

Destinasi wisatadari yang peneliti pahami yaitu sebuah daerah atau wilayah yang di dalamnya ada sebuah objek wisata yang bisa dikunjungi oleh masyarakat maupun wisatawan yang datang dari berbagai daerah dan luar negeri. Objek wisata seperti yang peneliti ketahui, terbagi menjadi beberapa kelompok, ada objek wisata alam yaitu yang menampilkan cagar alam yang masih asri, kemudian ada objek wisata sosial budaya yang bisa dijadikan daya tarik dari segi peninggalan sejarahnya, museum, situs arkeologi, adat dan kerajinan tangan, serta ada pula objek wisata buatan, di mana objek ini sengaja diciptakan dan dibuat dengan tema khusus untuk menarik wisatawan.

Pada penelitian ini, peneliti tertarik untuk melakukan penelitian di objek wisata buatan, yaitu Taman Mini Indonesia Indah
(TMII). Taman Mini Indonesia Indah (TMII) merupakan suatu kawasan taman wisata dan juga sebagai objek wisata yang bertema budaya Indonesia, yang berlokasi di Jakarta Timur. Diketahui dalam www.tamanmini.com, Taman Mini Indonesia Indah (TMII) mempunyai area seluas kurang lebih 150 hektar atau 1,5 kilometer persegi, di mana objek wisata ini terbilang sangat luas. Taman Mini Indonesia Indah (TMII) memberikan gambaran budaya dan kepulauan Indonesia yang diwujudkan melalui Anjungan Daerah dengan mewakili setiap suku-suku bangsa yang berada di 33 (tiga puluh tiga) Provinsi di Indonesia.Tidak hanya itu saja, Taman Mini Indonesia Indah (TMII) memiliki banyak wahana dan museum yang bermanfaat untuk hiburan, menambah wawasan bahkan kegiatan edukasi bagi pelajar. Salah satunya adalah wisata Dunia Air Tawar dan Dunia Serangga TMII yang terletak di dalam area Taman Mini Indonesia Indah (TMII).

Dunia Air Tawar dan Dunia Serangga TMII seperti yang banyak orang ketahui adalah suatu objek wisata buatan, di mana di dalamnya terdapat berbagai macam spesies ikan yang hidup di air tawar juga terdapat berbagai macam jenis spesies serangga, yang dibangun dengan tujuan untuk edukasi dan hiburan. Objek wisata buatan ini adalah satusatunya objek rekreasi yang khusus menyajikan koleksi seluruh aneka jenis ikan air tawar yang asalnya dari bermacam perairan di Indonesia ataupun bagian negeri lainnya. Sedangkan Dunia Serangga adalah objek wisata yang memperkenalkan keanekaragaman serangga untuk merangsang minat serta kepedulian masyarakat terhadap peran lingkungan di sekitarnya. Hal inilah yang membuat peneliti tertarik untuk melakukan penelitian di Dunia Air Tawar dan Dunia Serangga TMII. Peneliti juga mendapatkan informasi bahwa Dunia Air Tawar TMII ini merupakan taman biota air tawar terbesar dan terlengkap ke dua di dunia 
SadarWisata: JurnalPariwisata

(p-ISSN 1858-0112, e-ISSN 15537-37677
Volume 3 No.2 Desembar Tahun 2020

http://jurnal.unmuhjember.ac.id/index.php/wisata serta terbesar di Asia. Hal ini cukup menjadi daya tarik tersendiri untuk objek wisata buatan ini.

Dunia Air Tawar dan Dunia Serangga TMII cukup mudah untuk dijangkau, harga tiket untuk berwisata juga relatif murah. Kita bisa mengakses informasi mengenai Dunia Air Tawar dan Dunia Serangga TMII melalui media internet yaitu situs pribadi Dunia Air Tawar dan Dunia Serangga TMII serta melalui media sosial Instagram dan Youtube. Saat berkunjung ke Dunia Air Tawar dan Dunia Serangga TMII peneliti melihat di dalamnya terdapat fasilitas yang cukup baik untuk melengkapi kebutuhan para pengunjung. Fasilitas yang memadai cukup untuk keberlangsungan objek wisata ini.Peneliti memahami bahwa, objek ini penting untuk dikembangkan dan dilestarikan. Hal ini dikarenakan bahwa Dunia Air Tawar dan Dunia Serangga TMII menyajikan banyak informasi yang mengedukasi para wisatawan yang berkunjung. Dunia Air Tawar dan Dunia Serangga TMII juga bisa menjadi tempat rekreasi yang menghibur bagi banyak masyarakat, karena penyajiannya membuat wisatawan dapat merasakan suasana seperti sedang berada di dunia air tawar dan di sarang serangga. Namun, dari data pengunjung yang peneliti dapatkan dari arsip Dunia Air Tawar dan Dunia Serangga TMII, terdapat penurunan jumlah pengunjung. Hal ini dapat dilihat dari tabel di bawah ini.

Tabel 1.Data Jumlah Kunjungan Pengunjung Objek WisataDunia Air Tawar dan Dunia Serangga TMII, Jakarta TimurTahun 2017 - 2019

\begin{tabular}{|c|c|c|c|}
\hline \multicolumn{4}{|c|}{ Data Pengunjung Dunia Air Tawar dan Dunia } \\
Serangga - TMII Periode 2017-2019 \\
\hline $\begin{array}{c}\text { Umum dan } \\
\text { Rombongan }\end{array}$ & Tahun & Tahun & Tahun \\
\hline Bulan & $\mathbf{2 0 1 7}$ & $\mathbf{2 0 1 8}$ & $\mathbf{2 0 1 9}$ \\
\hline Januari & 28038 & 23689 & 21384 \\
\hline Februari & 16558 & 25649 & 24059 \\
\hline Maret & 28218 & 29697 & 30417 \\
\hline April & 32364 & 30378 & 24598 \\
\hline
\end{tabular}

\begin{tabular}{|c|c|c|c|}
\hline \multicolumn{4}{|c|}{$\begin{array}{c}\text { Data Pengunjung Dunia Air Tawar dan Dunia } \\
\text { Serangga - TMII Periode 2017-2019 }\end{array}$} \\
\hline $\begin{array}{c}\text { Umum dan } \\
\text { Rombongan }\end{array}$ & Tahun & Tahun & Tahun \\
\hline Mei & 24478 & 18522 & 6762 \\
\hline Juni & 24429 & 33298 & 34143 \\
\hline Juli & 24361 & 19132 & 18681 \\
\hline Agustus & 14893 & 11546 & 12142 \\
\hline September & 18877 & 16913 & 18460 \\
\hline Oktober & 27432 & 23708 & 33043 \\
\hline November & 29089 & 24332 & 27523 \\
\hline Desember & 40533 & 41296 & 34008 \\
\hline Total & 309270 & 298160 & 285220 \\
\hline
\end{tabular}

Sumber: Arsip Dunia Air Tawar dan Dunia Serangga TMII 2020.

Berdasarkan data pengunjung di atas, peneliti memahami dalam 3 (tiga) tahun terakhir terlihat penurunan yang cukup drastis yang terjadi pada tahun 2017 sampai 2019. Hal ini penting untuk menjadi perhatian bagi peneliti dalam mengetahui penyebab apa saja yang memicu terjadinya penurunan jumlah pengunjung pada Dunia Air Tawar dan Dunia Serangga TMII.

Menurunnya angka pengunjung dalam suatu objek wisata, bisa disebabkan dari berbagai hal, contohnya bisa dilihat dari segi fasilitas yang belum maksimal untuk melengkapi kebutuhan pengunjung, juga bisa dari segi daya tarik di dalamnya yang tidak dirawat secara berkala dan juga bisa dilihat dari segi promosi yang digunakan untuk menarik pengunjung. Namun dalam hal ini, peneliti menyadari, adanya kegiatan yang kurang maksimal dalam melakukan promosi untuk menarik minat berkunjung. Berikut terdapat gambar yang menunjukkan adanya kegiatan promosi yang dilakukan melalui media Instagram seperti gambar di bawah ini: Gambar 1. Konten Kegiatan Promosi Objek WisataDunia Air Tawar dan Dunia Serangga TMII, Jakarta Timur Melalui Media Instagram 


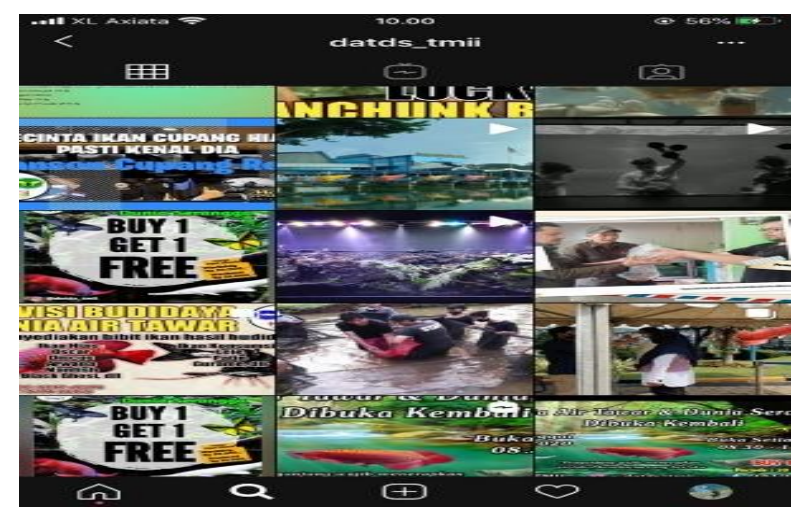

Sumber: Media Instagram Dunia Air Tawar dan Dunia Serangga TMII 2020.

Dari analisa media sosial Dunia Air Tawar dan Dunia Serangga TMII, konten yang diunggah melalui media sosial Instagram hanya berupa aktivitas yang diadakan dalam event yang diselenggarakan, serta konten-konten yang berisi ucapan terima kasih telah berkunjung ke Dunia Air Tawar dan Dunia Serangga TMII. Terdapat pula konten yang mengajak untuk datang ke Dunia Air Tawar dan Dunia Serangga TMII tetapi bentuk penyajiannya masih belum terlihat menarik menurut peneliti. Berikutnya terdapat juga bentuk promosi melalui media cetak yaitu brosur yang disediakan di dalamnya yang menjelaskan secara singkat mengenai Dunia Air Tawar dan Dunia Serangga TMII dan tersedia paket untuk program kegiatan yang bisa dilaksanakan. Singkatnya, peneliti berpendapat bahwa kegiatan promosi atau pengelolaan media sosial Dunia Air Tawar dan Dunia Serangga TMII belum dilakukan maksimal.

Peneliti menyadari bahwa fasilitas wisata dan kegiatan promosi itu penting diadakan dan dilakukan dengan maksimal sebagai salah satu bentuk usaha untuk menarik minat pengunjung ke suatu objek wisata. Maka berdasarkan penjelasan latar belakang masalah ini, peneliti tertarik untuk melakukan penelitian dengan judul "Pengaruh Fasilitas Wisata dan Promosi Terhadap Minat Berkunjung di Dunia Air Tawar dan Dunia Serangga TMII ".

\section{METODOLOGI}

Penelitian ini dilaksanakan di Dunia Air Tawar dan Dunia Serangga TMII.Pada penelitian ini penulis menggunakanmetode penelitian kuantitatif dengan jenis penelitian asosiatif kausal. Dalam penelitian ini, jumlah populasi diambil dari data jumlah pengunjung yang pernah berkunjung di Dunia Air Tawar dan Dunia Serangga TMII pada tahun 2019 yaitu sebesar 285.220 pengunjung. Penulis menggunakan probability sampling dengan pendekatan simple random sampling. Di mana penulis akan memberikan peluang atau kesempatan yang sama bagi setiap anggota populasi untuk dipilih sebagai sampel.

Menurut Sugiyono (2016:120), probability sampling merupakan metode pengumpulan sampel yang membagikan kesempatan yang serupa untuk tiap faktor( bagian) populasi buat diseleksi jadi badan ilustrasi.. Sederhana random sampling dibilang sederhana( simpel) sebab pengumpulan badan ilustrasi dari populasi dicoba dengan cara random tanpa mencermati jenjang yang terdapat dalam populasi itu. Sugiyono (2016:120).

Untuk menghitung penentuan jumlah sampel dari populasi tertentu yang dikembangkan, maka digunakan rumus Slovin dalam Riyanto dan Hatmawan (2020:12) mengatakan bahwa penentuan jumlah sampel berdasarkan rumus Slovin telah banyak digunakan oleh peneliti, karena pendekatan rumus Slovin dinilai mudah dan praktis dalam penggunannya. Dalam menentukan jumlah sampel yang akan dipilih, penulis menggunakan tingkat kesalahan sebesar 10\% dengan jumlah populasi sebesar 285.220 pengunjung, maka hasil perhitungan rumus menggunakan rumus Slovin Hasil menunjukkan 100 (seratus) sampel untuk pengisian kuesioner pada penelitian ini, dengan menggunakan tingkat kesalahan 10\% dalam rumus Slovin. Peneliti memahami bahwa jumlah populasi yang ada pada 
SadarWisata: JurnalPariwisata

(p-ISSN 1858-0112, e-ISSN 15537-37677

penelitian ini relatif besar, oleh karena itu, peneliti memutuskan untuk mengambil 100 (seratus) sampel.

Penelitian ini juga menggunakan alat bantu skala Likert. Menurut Sugiyono (2016:134), skala likert ialah rasio yang dipakai buat mengukur tindakan, opini, serta anggapan seorang ataupun segerombol orang mengenai kejadian sosial. Dengan Rasio Likert, hingga elastis yang hendak diukur dipaparkan jadi penanda elastis. Setelah itu penanda itu dijadikan bagaikan titik dorong buat menata item- tem instrument yang bisa berbentuk statment ataupun persoalan.

Suryani dan Hendriyadi (2015:132) bahwa: Dalam perkembangannya, Skala Likert ini sudah dimodifikasi dengan berbagai bentuk, mulai dari empat titik hingga sembilan titik. Berikut ini adalah Skala Likert dengan empat titik:

1. Sangat tidak setuju (Strongly Disagree).

2. Tidak setuju (Disagree).

3. Setuju (Agree).

4. Sangat Setuju (Strongly Agree).

Maka, berdasarkan pengertian tersebut, dalam penelitian ini peneliti menggunakan Skala Likert dengan empat titik pilihan jawaban yang digunakan.

Dalam penelitian ini menggunakan metode analisis statistic dengan bantuan Software Statistical Product and Service Solutions (SPSS) versi 24.0. Dimana pada penelitian ini akan menggunakan uji validitas, uji reliabilitas, uji asumsi klasik (uji normalitas, uji multikolinearitas, uji heteroskedastisitas dan uji autokorelasi), analisis regeresi linear berganda (uji-t parsial, uji F simultan, dan analisis koefisien korelasi dan determinasi). Dimana variabel ini akan diteliti dan diukur pada penelitian ini adalah variabel X1yaitu fasilitas wisata, X2promosi dan Y minat berkunjung.
Volume 3 No.2 Desembar Tahun 2020

http://jurnal.unmuhjember.ac.id/index.php/wisata

Dari penyebaran kuesioner profil responden dapat dijabarkan menjadi berbagai karakteristik responden yaitu berdasarkan jenis kelamin, usia, domisili, pekerjaan dan pendapatan sebagai berikut :

Tabel 2. Jenis Kelamin

\begin{tabular}{|c|c|c|}
\hline $\begin{array}{c}\text { Jenis } \\
\text { Kelamin }\end{array}$ & Frekuensi & $\begin{array}{c}\text { Presentase } \\
(\%)\end{array}$ \\
\hline Laki-Laki & 37 & $37 \%$ \\
\hline Perempuan & 63 & $63 \%$ \\
\hline Jumlah & 100 & $100 \%$ \\
\hline
\end{tabular}

Sumber : Hasil Olah Data Penulis, 2020

Hasil

pengolahan

data

respondenberjenis kelamin laki-laki sebanyak $37 \%$ dari total responden dan responden berjenis kelamin perempuan sebanyak $63 \%$ dari total responden. Maka dalam hal ini dapat dikatakan bahwa responden berjenis kelamin perempuan lebih banyak berkunjung ke Dunia Air Tawar dan Dunia Serangga TMII.

Tabel 3. Usia

\begin{tabular}{|c|c|c|}
\hline Umur & Frekuensi & Presentase (\%) \\
\hline$<20$ Tahun & 30 & $30 \%$ \\
\hline$>$ 50 Tahun & 3 & $3 \%$ \\
\hline 21-30 Tahun & 52 & $52 \%$ \\
\hline 31-40 Tahun & 8 & $8 \%$ \\
\hline 41-50 Tahun & 7 & $7 \%$ \\
\hline Jumlah & 100 & $100 \%$ \\
\hline
\end{tabular}

Sumber : Hasil Olah Data Penulis, 2020

Sesuai data yang disajikan di atas, dapat diketahui bahwa sebagian besar responden merupakan pengunjung dengan rentang usia 21-30 Tahun, yaitu sebesar 52\%, sedangkan pengunjung dengan rentang usia < 20 Tahun yaitu sebesar 30\%, pengunjung dengan usia 31 - 40 Tahun sebesar $8 \%$, dan pengunjung dengan rentang usia 41-50 Tahun sebesar $7 \%$, juga pengunjung dengan rentang usia > 50 Tahun sebesar $3 \%$. 
Tabel 4. Domisili

\begin{tabular}{|c|c|c|}
\hline Domisili & Frekuesnsi & Presentase (\%) \\
\hline Bali & 5 & $5 \%$ \\
\hline Banten & 1 & $1 \%$ \\
\hline D.I Yogyakarta & 2 & $2 \%$ \\
\hline DKI Jakarta & 53 & $53 \%$ \\
\hline Jawa Barat & 38 & $38 \%$ \\
\hline Sulawesi & 1 & $1 \%$ \\
\hline Jumlah & 100 & $100 \%$ \\
\hline
\end{tabular}

Sumber : Hasil Olah Data Penulis, 2020.

Hasil tabel di atas, dapat diketahui bahwa sebagian besar responden merupakan pengunjung yang berasal dari Bali sebesar $5 \%$, sedangkan engunjungyang berasal dari Banten yaitu sebesar $1 \%$, pengunjung yang berasal dari D.I Yogyakarta sebesar 2\%, pengunjung yang berasal dari DKI Jakarta yaitu sebesar $53 \%$, pengunjungyang berasal dari Jawa Barat sebesar 38\%, dan pengunjungyang berasal dari Sulawesi sebesar $1 \%$.

Tabel 5. Pekerjaan

\begin{tabular}{|c|c|c|}
\hline Pekerjaan & Frekuesnsi & Presentase (\%) \\
\hline Ibu Rumah Tangga & 5 & $5 \%$ \\
\hline Pegawai Negeri & 16 & $16 \%$ \\
\hline Pegawai Swasta & 28 & $28 \%$ \\
\hline Pelajar/Mahasiswa & 45 & $45 \%$ \\
\hline Wirausaha & 4 & $4 \%$ \\
\hline Yang Lain & 2 & $2 \%$ \\
\hline Jumlah & 100 & $100 \%$ \\
\hline
\end{tabular}

Sumber : Hasil Olah Data Penulis, 2020

Berdasarkan tabel di atas, dapat diketahui bahwa sebagian besar responden merupakan pengunjung mempunyai status sebagai pelajar/mahasiswa yaitu sebesar $45 \%$, sedangkan pengunjung dengan pekerjaan sebagaipegawai negeri yaitu sebesar $16 \%$, pengunjung yang merupakan wirausaha yaitu sebesar $4 \%$, pengunjung yang merupakan ibu rumah tangga yaitu sebesar 5\%, pengunjung dengan status pekerjaan yainlain sebesar $2 \%$ dan pengunjung dengan pekerjaansebagai pegawai swasta sebesar $28 \%$.
Tabel 6. Pendapatan

\begin{tabular}{|c|c|c|}
\hline Pendapatan & Frekuensi & Presentase (\%) \\
\hline < Rp. 1.000.000 & 34 & $34 \%$ \\
\hline > Rp. 10.000.000 & 4 & $4 \%$ \\
\hline Rp. 1.000.000 - Rp. 2.500 .000 & 17 & $17 \%$ \\
\hline Rp. 2.500.000 - Rp. 5.000.000 & 24 & $24 \%$ \\
\hline Rp. 5.000.000 - Rp. 7.500.000 & 11 & $11 \%$ \\
\hline Rp. 7.500.000 - Rp. 10.000.000 & 10 & $10 \%$ \\
\hline Jumlah & 100 & $100 \%$ \\
\hline
\end{tabular}

Sumber : Hasil Olah Data Penulis, 2020

Data diatas menjelaskan bahwa pendapatan pengunjung yang sudah pernah mengunjungi Dunia Air Tawar dan Dunia Serangga TMIIpendapatan< Rp. 1.000 .000 sebesar 34\%, pengunjung berpendapatan diantara Rp.1.000.000 - Rp. 2.500 .000 sebesar 17\%, pengunjung berpendapatan diantara Rp. 2.500.000 - Rp. 5.000 .000 sebesar 24\% dan diantara Rp. 5.000.000 - Rp. 7.500 .000 sebesar 11\%, pengunjung berpendapatan diantara Rp. 7.500 .000 - Rp. 10.000.000 sebesar $10 \%$ dan pengunjung berpendapatan > Rp. 10.000 .000 sebesar $4 \%$.

Riyanto (2020:137) mengatakan bahwa uji asumsi klasik adalah uji persyaratan yang digunakan untuk uji regresi dengan metode estimasi Ordinal Least Squares (OLS). Uji asumsi klasik pada umumnya ada 4 (empat), yaitu uji normalitas, uji autokorelasi, uji multikolinearitas dan uji heteroskedastisitas.

Tabel 7. Hasil Uji Normalitas

\begin{tabular}{|c|c|c|c|}
\hline \multicolumn{4}{|c|}{ One-Sample Kolmogorov-Smirnov Test } \\
\hline & & & $\begin{array}{c}\text { Unstandardized } \\
\text { Residual }\end{array}$ \\
\hline \multicolumn{3}{|c|}{$\mathrm{N}$} & 100 \\
\hline \multirow{2}{*}{$\begin{array}{c}\text { Normal } \\
\text { Parameters }^{\mathrm{a}, \mathrm{b}}\end{array}$} & \multicolumn{2}{|c|}{ Mean } & 0.0000000 \\
\hline & \multicolumn{2}{|c|}{ Std. Deviation } & 3.11974239 \\
\hline \multirow{3}{*}{$\begin{array}{c}\text { Most } \\
\text { Extreme } \\
\text { Differences }\end{array}$} & \multicolumn{2}{|c|}{ Absolute } & 0.110 \\
\hline & \multicolumn{2}{|c|}{ Positive } & 0.110 \\
\hline & \multicolumn{2}{|c|}{ Negative } & -0.060 \\
\hline \multicolumn{3}{|c|}{ Test Statistic } & 0.110 \\
\hline \multicolumn{3}{|c|}{ Asymp. Sig. (2-tailed) } & $.004^{\mathrm{c}}$ \\
\hline \multirow{3}{*}{$\begin{array}{c}\text { Monte Carlo } \\
\text { Sig. (2- } \\
\text { tailed) }\end{array}$} & \multicolumn{2}{|c|}{ Sig. } & $.167^{\mathrm{d}}$ \\
\hline & \multirow{2}{*}{$\begin{array}{c}99 \% \\
\text { Confidence } \\
\text { Interval }\end{array}$} & $\begin{array}{l}\text { Lower } \\
\text { Bound }\end{array}$ & 0.157 \\
\hline & & Upper & 0.176 \\
\hline
\end{tabular}


SadarWisata: JurnalPariwisata

(p- ISSN 1858-0112, e-ISSN 15537-37677

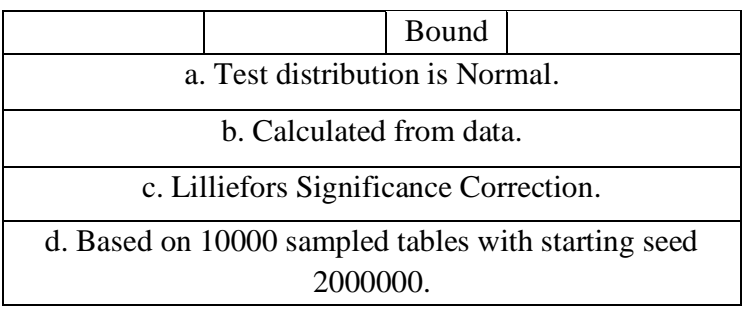

Sumber: Hasil Olah Data Penulis, 2020

Menurut hasil uji normalitas diketahui nilai signifikansi $0,167>0,05$ maka dapat disimpulkan bahwa nilai residual berdistribusi normal.

Tabel 8. Hasil Uji Multikolinearitas

\begin{tabular}{|c|c|c|c|}
\hline \multicolumn{2}{|c|}{} & \multicolumn{2}{c|}{ Collinearity Statistics } \\
\cline { 2 - 4 } \multicolumn{2}{|c|}{ Model } & Tolerance & VIF \\
\hline 1 & (Constant) & & \\
\cline { 2 - 4 } & Fasilitas Wisata(X1) & 0.777 & 1.286 \\
\cline { 2 - 4 } & Promosi (X2) & 0.777 & 1.286 \\
\hline
\end{tabular}

Sumber: Hasil Olah Data Penulis, 2020

Hasil uji multikolinearitas pada Fasilitas Wisata (X1) hasil nilai Tolerance 0.777> 0,10 dan nilai VIF $1.286<\mathbf{1 0 , 0 0 .}$ Selanjutnya pada Promosi (X2) hasil nilai Tolerance $0.777>\mathbf{0 , 1 0}$ dan nilai VIF $1.286<$ 10,00. Dapat disimpulkan bahwa tidak ada gejala multikolinearitas.

Tabel 9. Hasil Uji Autokorelasi

\begin{tabular}{|c|c|c|c|c|c|}
\hline \multicolumn{6}{|c|}{ Model Summary ${ }^{b}$} \\
\hline $\begin{array}{l}\text { Mode } \\
1\end{array}$ & $\mathrm{R}$ & $\begin{array}{c}\mathrm{R} \\
\text { Square }\end{array}$ & $\begin{array}{l}\text { Adjusted } \\
\text { R Square }\end{array}$ & $\begin{array}{l}\text { Std. } \\
\text { Error }\end{array}$ & $\begin{array}{l}\text { Durbin- } \\
\text { Watson }\end{array}$ \\
\hline 1 & $.591^{\mathrm{a}}$ & 0.349 & 0.336 & 3.152 & 1.623 \\
\hline \multicolumn{6}{|c|}{ a. Predictors: (Constant), Promosi (X2), Fasilitas Wisata(X1) } \\
\hline b. De & & le: M & n & & \\
\hline
\end{tabular}

Sumber: Hasil Olah Data Penulis, 2020

Berdasarkan hasil uji di atas, pada tabel Durbin Watson, terdapat angka D-W di bawah -2 sebesar +1.623 berarti terdapat autokorelasi positif. Dikatakan tidak terjadi gejala autokorelasi.
Volume 3 No.2 Desembar Tahun 2020

http://jurnal.unmuhjember.ac.id/index.php/wisata

Tabel 10. Hasil Uji Heteroskedastisitas

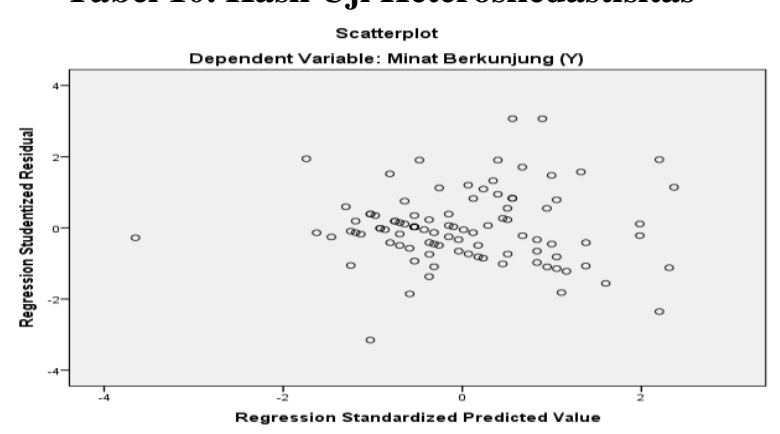

Sumber: Hasil Olah Data Penulis, 2020

Gambar data di atas bahwa dalam tahap uji heteroskedastisitas, kesimpulannya adalah tidak terjadi heteroskedastisitas.

Tabel 11. Hasil Uji Regresi Linear Berganda

\begin{tabular}{|c|c|c|c|c|c|c|}
\hline \multicolumn{7}{|c|}{ Coefficients $^{\mathrm{a}}$} \\
\hline \multirow{2}{*}{\multicolumn{2}{|c|}{ Model }} & \multicolumn{2}{|c|}{$\begin{array}{l}\text { Unstandardized } \\
\text { Coefficients }\end{array}$} & \multirow{2}{*}{$\begin{array}{l}\begin{array}{l}\text { Standardized } \\
\text { Coefficients }\end{array} \\
\text { Beta }\end{array}$} & \multirow[b]{2}{*}{$\mathrm{T}$} & \multirow[b]{2}{*}{ Sig. } \\
\hline & & B & $\begin{array}{l}\text { Std. } \\
\text { Error }\end{array}$ & & & \\
\hline 1 & (Constant) & 16.853 & 2.898 & & 5.815 & $\begin{array}{l}0.0 \\
00\end{array}$ \\
\hline & $\begin{array}{l}\text { Fasilitas } \\
\text { Wisata } \\
\text { (X1) }\end{array}$ & 0.419 & 0.060 & 0.580 & 7.043 & $\begin{array}{l}0.0 \\
00\end{array}$ \\
\hline & $\begin{array}{l}\text { Promosi } \\
(\mathrm{X} 2)\end{array}$ & 0.360 & 0.090 & 0.374 & 3.989 & $\begin{array}{l}0.0 \\
00\end{array}$ \\
\hline
\end{tabular}

Sumber: Hasil Olah Data Penulis, 2020

Dari hasil pengolahan analisis regresi linear berganda yang telah dilakukan, maka didapatkan persamaan regresi sebagai berikut: $\mathrm{Y}=16.853+0.419 \mathrm{X} 1+0.360 \mathrm{X} 2+2.898$

Konstanta sebesar 16.853 dapat dinyatakan sebagai berikut: apabila nilai variabel X1 dan $\mathrm{X} 2$ sama dengan 0 maka nilai $\mathrm{Y}$ adalah 16.853 dimana dapat diartikan bahwa nilai minat berkunjung di Dunia Air Tawar dan Dunia Serangga TMII dilihat dari fasilitas wisata dan promosi adalah sebesar 16.853. Maka dapat disimpulkan fasilitas wisata dan promosi dapat mempengaruhi minat berkunjung di Dunia Air Tawar dan Dunia Serangga TMII. 
Tabel 12.Hasil Uji-t ParsialFasilitas Wisata

\begin{tabular}{|l|l|l|l|l|}
\hline \multicolumn{5}{|c|}{ Coefficients $^{\mathrm{a}}$} \\
\hline \multicolumn{2}{|c|}{ Model } & T tabel & T hitung & Sig. \\
\hline 1 & Fasilitas Utama & 2.627 & 3.929 & 0.000 \\
\hline 2 & $\begin{array}{l}\text { Fasilitas } \\
\text { Pendukung }\end{array}$ & 2.627 & 3.104 & 0.002 \\
\hline 3 & \begin{tabular}{l} 
Fasilitas Penunjang \\
\hline
\end{tabular} & 2.627 & 4.633 & 0.000 \\
\hline
\end{tabular}

Sumber: Hasil Olah Data Penulis, 2020

Diketahui nilai signifikansi untuk pengaruh $\mathrm{X} 1$ terhadap $\mathrm{Y}$ didapati nilai $\mathrm{t}$ hitung lebih besar dari t tabel sehingga dapat disimpulkan bahwa berdasarkan hasil uji secara parsial terdapat pengaruh Fasilitas Wisata (X1) terhadap Minat Berkunjung (Y) secara signifikan.

Tabel 13Hasil Uji-t ParsialPromosi

\begin{tabular}{|c|c|c|c|c|}
\hline \multicolumn{5}{|c|}{ Coefficients $^{\mathrm{a}}$} \\
\hline & del & $\mathrm{T}$ tabel & T hitung & Sig. \\
\hline 1 & $\begin{array}{lr}\text { Keberagaman } & \text { Media } \\
\text { Promosi } & \text { yang } \\
\text { Digunakan } & \\
\end{array}$ & 2.627 & 8.877 & 0.000 \\
\hline 2 & Daya Tarik Promosi & 2.627 & 20.406 & 0.002 \\
\hline 3 & $\begin{array}{ll}\text { Kejelasan } & \text { Pesan } \\
\text { dalam Promosi }\end{array}$ & 2.627 & 24.097 & 0.000 \\
\hline 4 & $\begin{array}{l}\text { Kelengkapan } \\
\text { Informasi dalam } \\
\text { Promosi }\end{array}$ & 2.627 & 16.105 & 0.000 \\
\hline
\end{tabular}

Sumber: Hasil Olah Data Penulis, 2020

Diketahui nilai signifikansi untuk pengaruh $\mathrm{X} 2$ terhadap $\mathrm{Y}$ didapati nilai $\mathrm{t}$ hitung lebih besar dari tabel sehingga dapat disimpulkan bahwa berdasarkan hasil uji secara parsial terdapat pengaruh Promosi (X2) terhadap Minat Berkunjung (Y) secara signifikan.

Tabel 14. Hasil Uji F Simultan

\begin{tabular}{|l|l|l|l|l|l|l|}
\hline \multicolumn{7}{|c|}{ ANOVA $^{\text {a }}$} \\
\hline \multirow{2}{*}{ Model } & $\begin{array}{l}\text { Sum of } \\
\text { Squares }\end{array}$ & Df & $\begin{array}{l}\text { Mean } \\
\text { Square }\end{array}$ & F & Sig. \\
\hline 1 & Regression & 516.494 & 2 & 258.247 & 25.998 & $.000^{\mathrm{b}}$ \\
\cline { 2 - 7 } & Residual & 963.546 & 97 & 9.933 & & \\
\cline { 2 - 7 } & Total & 1480.040 & 99 & & & \\
\hline
\end{tabular}

Sumber: Hasil Olah Data Penulis, 2020
Berdasarkan hasil tabel SPSS diketahui nilai signifikansi adalah sebesar 0.000. Dapat disimpulkan bahwa fasilitas wisata dan promosi secara simultan mempengaruhi minat berkunjung dengan nilai signifikansi $0.000<$ 0,01 dengan hasil Fhitung ( $25.998>4,83)$.

Tabel 15. Hasil Uji Koefisien Korelasi dan Determinasi

\begin{tabular}{|c|c|c|c|c|c|}
\hline \multicolumn{6}{|c|}{ Model Summary ${ }^{\mathbf{b}}$} \\
\hline $\begin{array}{l}\text { M } \\
\text { od } \\
\text { el }\end{array}$ & $\mathrm{R}$ & R Square & $\begin{array}{l}\text { Adjuste } \\
\text { d R R } \\
\text { Square }\end{array}$ & $\begin{array}{l}\text { Std. Error } \\
\text { of the } \\
\text { Estimate }\end{array}$ & $\begin{array}{l}\text { Durbin- } \\
\text { Watson }\end{array}$ \\
\hline 1 & $.591^{\mathrm{a}}$ & 0.349 & 0.336 & 3.152 & 1.623 \\
\hline \multicolumn{6}{|c|}{ a. Predictors: (Constant), Promosi (X2), Fasilitas Wisata(X1) } \\
\hline \multicolumn{6}{|c|}{ b. Dependent Variable: Minat Berkunjung (Y) } \\
\hline
\end{tabular}

Sumber: Hasil Olah Data Penulis, 2020

Menurut hasil olah data didapati korelasi rendah atau dapat dikatakan pengaruh antara Fasilitas Wisata dan Promosi terhadap Minat Berkunjung masuk dalam kategori sedang.Dari hasil penelitian, dapat dikatakan bahwa variabel (X1) Fasilitas Wisata dan (X2) Promosi memberikan pengaruh sebesar 34.9\% terhadap variabel (Y) yaitu Minat Berkunjung dan sisanya sebesar $65,1 \%$ dipengaruhi oleh faktor lain yang tidak diteliti.

\section{KESIMPULAN}

Berdasarkan hasil pengolahan data dan pembahasan pada penelitian ini, maka dapat disimpulkan bahwa dari hasil penelitian pada uji t parsial (X1) Fasilitas Wisata diketahui variabel bebas fasilitas wisata secara parsial memiliki pengaruh signifikan terhadap variabel terikat minat berkunjung. Selanjutnya (X2) Promosi diketahui variabel bebas promosi secara parsial memiliki pengaruh yang signifikan terhadap variabel terikat minat berkunjung. Hasil uji $\mathrm{F}$ dalam penelitian bahwa variabel fasilitas wisata dan promosi sebagai variabel bebas secara simultan mempengaruhi minat berkunjung. Hasil uji regresi linear berganda dengan konstanta 16.853 memberikan nilai positif dan memberikan ketepatan prediksi 
bahwa ada pengaruh yang terjadi antara (X1) Fasilitas Wisata dan (X2) Promosi terhadap (Y) Minat Berkunjung pada Dunia Air Tawar dan Dunia Serangga TMII.

\section{DAFTAR PUSTAKA}

Auladi, M., Mawardi, K., \& Sanawiri, B. (2017). Pegaruh City Branding Serta Tagline "Kediri Lagi" Terhadap Minat Berkunjung Wisatawan Domestik Kabupaten Kediri. Jurnal Administrasi Bisnis: Vol. 44, No.1,106

Adrian, D., \& Hidayat, W. (2017). Pengaruh Kualitas Produk Wisata, Kualitas Pelayanan dan Promosi Terhadap Kepuasan Pengunjung Objek Wisata Goa Kreo Semarang. Jurnal Ilmu Administrasi Bisnis: Volume 6, Nomor 2, 4.

Desy Agestia. (2016). Tinjauan Fasilitas Rekreasi Di Objek Wisata Taman Rekreasi Alam Mayang Kota Pekanbaru. JOM FISIP: Vol 3, No. 2, 4 .

Fitri, Aprilia. (2015). Pengaruh Word Of Mouth Terhadap Minat Berkunjung Serta Dampaknya Pada Keputusan Berkunjung. Jurnal Administrasi Bisnis: Vol. 24, No. 1, 2

Riyanto, Slamet.,\& Hatmawan, A. (2020). Metode Riset Penelitian Kuantitatif Penelitian di Bidang Manajemen, Teknik, Pendidikan dan Eksperimen. Sleman. Yogyakarta:PENERBIT

DEEPUBLISH (Grup Penerbitan CV Budi Utama).

Sugiarto, B., Bima, O., \& Asthararianty. (2019). Perancangan Promosi Wisata Bahari di Kawasan Pantai Cumpat, Keluraha Kedung Cowek, Surabaya. Jurnal DKVAdiwarna, Universitas Kristen Petra: Vol.2, No. 3.
Sugiyono. (2016). Metode Penelitian Pendekatan Kuantitatif Kualitatif dan R\&D. Bandung:Alfabeta..

Suharsimi, A. (2016). Prosedur Penelitian: Suatu Pendekatan Praktik. Jakarta: Rineka Cipta.

Sujarweni, W. V. (2014). Metode Penelitian: Lengkap, Praktis, dan Mudah Dipahami. Yogyakarta: Pustaka Baru Press

Sulaeman, A. (2018). Analisis Pengaruh Kualitas Pelayanan Dan Produk Terhadap Kepuasan Pelanggan Pada Pt.Cakrawala Citramega. (D. F. Pamulang, Ed.)

Suwena, I. K., \& Widyatmaja, I. G. (2017). Pengetahuan Dasar Ilmu Pariwisata. Pustaka Larasan.

Usman, H., \& Purnomo, A. (2009). Metodologi Penelitian Sosial. Jakarta: Bumi Aksara.

Yuliani. (2013). Strategi Komunikasi Dinas Kebudayaan Pariwisata Dan Kominfo (Disbudpar) Dalam Meningkatkan Kunjungan Wisatawan Di Desa Pampang Kota Samarinda. Universitas Mulawarman. 